\title{
Small Intestine Characteristics and Nutrient Retention in Broiler Chickens Submitted to Different Protein Regimes and Betaine Supplementation
}

\author{
Adi Ratriyanto* and Sunarto \\ Department of Animal Science, Faculty of Agriculture, Universitas Sebelas Maret, Surakarta, 57126, Indonesia
}

Article history

Submitted: 4 November 2019

Accepted: 11 February 2020

* Corresponding author:

E-mail: ratriyanto@staff.uns.ac.id

\begin{abstract}
This study was designed to determine the intestinal characteristics and nutrient retention of broiler chickens subjected to different protein regimes supplemented with betaine. Four experimental diets were formulated, consisting of two basal diets containing $20 \%$ and $23 \%$ crude protein (CP), both with and without betaine supplementation at the level of $0.14 \%$. The diets were applied to 180 broiler chickens that were randomly allotted to $2 \times 2$ factorial arrangement with five replicates of nine chickens each. The diet with $20.0 \% \mathrm{CP}$ generated better small intestine characteristics than the diet with $23.0 \% \mathrm{CP}$ as indicated by the longer ileum and total small intestine length $(\mathrm{P}<0.05)$. This improvement was associated with lessened $\mathrm{CP}$ excretion and improved dry matter $(\mathrm{DM})$ and $\mathrm{CP}$ retention $(\mathrm{P}<0.05)$ in the birds fed $20 \% \mathrm{CP}$. Furthermore, dietary betaine supplementation enhanced the ileum, total small intestine length, villus height, and villus-to-crypt ratio $(\mathrm{P}<0.05)$, indicating a greater surface area for nutrient absorption. This enhancement was reflected in the reduction of DM and CP excretion and improvement in DM and CP retention in the betaine supplemented group $(\mathrm{P}<0.05)$. Therefore, we conclude that feeding a diet of $20 \% \mathrm{CP}$ with betaine supplementation improved the small intestine characteristics and nutrient retention of broiler chickens.
\end{abstract}

Keywords: Betaine, Broilers, Environmental temperature, Nutrient absorption, Nutrient excretion

\section{Introduction}

The development of the digestive tract is an important factor that determines the growth performance and health of broiler chickens (Esmailzadeh et al., 2016) and affects the microbial population, which has important role in nutrient digestion and the immune system (Esmailzadeh et al., 2016; Ratriyanto and Mosenthin, 2018). Furthermore, the dietary protein level has an impact on the growth rate of the chickens (De Faria Filho et al., 2007; Moosavi et al., 2012). However, high environmental temperatures in tropical areas such as in Indonesia may obstruct the growth performance of broilers by limiting protein synthesis (Rashid et al., 2012). Several studies have shown that high environmental temperatures reduce protein synthesis, but feeding them with a higher protein level cannot compensate for this effect (Moosavi et al., 2012; Rashid et al., 2012). Other studies discovered that feeding broiler chickens with higher protein levels in a high-temperature environment suppressed their growth rate (Moosavi et al., 2012; Gous et al., 2018), which could be attributed to their increased heat production (Daghir, 2009). Feeding them with a high protein level also increased nitrogen excretion from their bodies, indicating an inefficient use of nutrients (De Faria Filho et al., 2007; Moosavi et al., 2012). Therefore, it is necessary to provide a precise protein level for broiler chickens in tropical areas.

The use of betaine (trimethyl glycine) in poultry diet has increased in the last decades and commonly has aimed to improve the growth performance and carcass characteristics (Li et al., 2011; Rao et al., 2011). Betaine is a methyl group $\left(\mathrm{CH}_{3}\right)$ donor and is involved in protein and energy metabolism (Ratriyanto and Mosenthin, 2018). Dietary betaine can increase methionine availability, which leads to an improvement in protein availability (Ratriyanto et al., 2009; Rao et al., 2011). This function of betaine can improve protein efficiency through supplementing with betaine and reducing the protein level in the diet (Li et al., 2011; Ratriyanto et al., 2014). Betaine also acts as an organic osmolyte by stabilizing intestinal epithelial cells and supporting intestinal microbial growth (Metzler-Zebeli et al., 2009; Weiss et al., 2013), which are reflected in the improvement of nutrient retention and the growth 
performance of broiler chickens (El-Husseiny et al., 2007; Chand et al., 2017).

Many studies have shown the positive effects of dietary betaine supplementation in poultry as indicated by the improvement in growth performances and carcass quality (Rao et al., 2011; Sakomura et al., 2013; Liu et al., 2019). Currently, there are only a small number of studies focusing on the impacts of dietary betaine on the intestinal characteristics and nutrient retention of broiler chickens and the responses observed in these studies vary (Sayed and Downing, 2011; Sakomura et al., 2013). Therefore, the objective of this study was to determine the intestinal characteristics and nutrient retention of broiler chickens submitted to different protein regimes supplemented with betaine.

\section{Materials and Methods}

\section{Animals and diets}

In total, 180 one-day-old unsexed Lohmann broiler chickens were randomly allocated into the four dietary treatments with five replicates of nine chickens each. The arrangement of the treatments corresponds to a $2 \times 2$ factorial design with two levels of crude protein (CP, 20 and 23\%) and two levels of betaine supplementation ( $0 \%$ and $0.14 \%$ ).

The basal diet was formulated according to the standard of the National Research Council (1994) except for the protein levels of $20 \%$ and $23 \%$, and each protein level contained the same amount of metabolizable energy, namely 3,200 $\mathrm{kcal} / \mathrm{kg}$ (Table 1). Each protein level was fed without supplementation (Control) or supplemented with $0.14 \%$ betaine (Betaine). The supplementation of betaine to the basal diets was performed at the expense of corn, following the procedure used by Ratriyanto et al. (2014).

\section{Determination of intestinal characteristics}

The chickens were reared in 20 floor pens $(1 \times 1 \mathrm{~m})$ under natural temperature conditions until 35 days of age. The average ambient temperature at the midday during the experiment was $32.9^{\circ} \mathrm{C}$. Water and feed were supplied ad libitum. On day 35 , two chickens per pen (40 chickens in total) were randomly selected and slaughtered after fasting for 12 hours to measure their intestinal characteristics. The small intestine was removed from each bird and the lengths of the duodenum, jejunum, and ileum were measured using a gauge. The villus height and crypt depth were determined using a $1 \mathrm{~cm}$ section of distal jejunum following the procedure of Kettunen et al. (2001a). The sections were fixed in a $4 \%$ paraformaldehyde solution and dehydrated thereafter. The samples were set into paraffin blocks, cut at $5 \mu \mathrm{m}$, and stained with hematoxylineosin. A cross-section of each sample was captured at $40 \times$ magnification with a digital camera attached to a microscope. Villus height was measured from the base to the top of the villi and crypt depth was measured from the base of the villi to the base of the crypt as presented in Figure 1 (Dos Santos et al., 2018). The villus/crypt ratio was calculated as villus height divided by the mucosal crypt depth in each preparation (Kettunen et al., 2001a).

Table 1. Composition (\%) and nutrient content of experimental diets

\begin{tabular}{|c|c|c|c|c|}
\hline \multirow[t]{2}{*}{ Ingredients } & \multicolumn{2}{|c|}{ CP 20\% } & \multicolumn{2}{|c|}{ CP 23\% } \\
\hline & Control & Betaine & Control & Betaine \\
\hline Yellow corn & 56.75 & 56.61 & 55.00 & 54.86 \\
\hline Rice bran & 10.35 & 10.35 & 4.93 & 4.93 \\
\hline Soybean meal & 20.60 & 20.60 & 25.00 & 25.00 \\
\hline Fishmeal & 7.00 & 7.00 & 10.00 & 10.00 \\
\hline Coconut oil & 3.60 & 3.60 & 3.95 & 3.95 \\
\hline L-lysine $\mathrm{HCl}$ & 0.08 & 0.08 & 0.00 & 0.00 \\
\hline$D L$-methionine & 0.11 & 0.11 & 0.07 & 0.07 \\
\hline Dicalcium phosphate & 0.50 & 0.50 & 0.10 & 0.10 \\
\hline Limestone & 0.56 & 0.56 & 0.50 & 0.50 \\
\hline Premix ${ }^{*}$ & 0.20 & 0.20 & 0.20 & 0.20 \\
\hline $\mathrm{NaCl}$ & 0.25 & 0.25 & 0.25 & 0.25 \\
\hline Betaine & - & 0.14 & - & 0.14 \\
\hline \multicolumn{5}{|l|}{ Nutrient content } \\
\hline Crude protein (\%) & 20.00 & 19.99 & 23.00 & 22.98 \\
\hline Metabolizable energy $(\mathrm{kcal} / \mathrm{kg})$ & 3,200 & 3,195 & 3,200 & 3,195 \\
\hline Crude fiber (\%) & 7.07 & 7.06 & 6.66 & 6.65 \\
\hline Methionine (\%) & 0.50 & 0.50 & 0.51 & 0.51 \\
\hline Lysine (\%) & 1.18 & 1.18 & 1.20 & 1.20 \\
\hline Calcium (\%) & 1.01 & 1.01 & 1.01 & 1.01 \\
\hline Available phosphorus (\%) & 0.48 & 0.48 & 0.48 & 0.48 \\
\hline
\end{tabular}

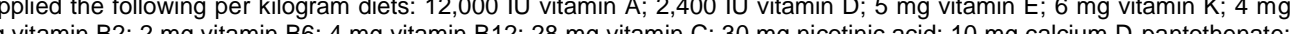
$150 \mathrm{mg}$ electrolytes containing $\mathrm{Na}, \mathrm{K}, \mathrm{Ca}$, and $\mathrm{Mg}$. 


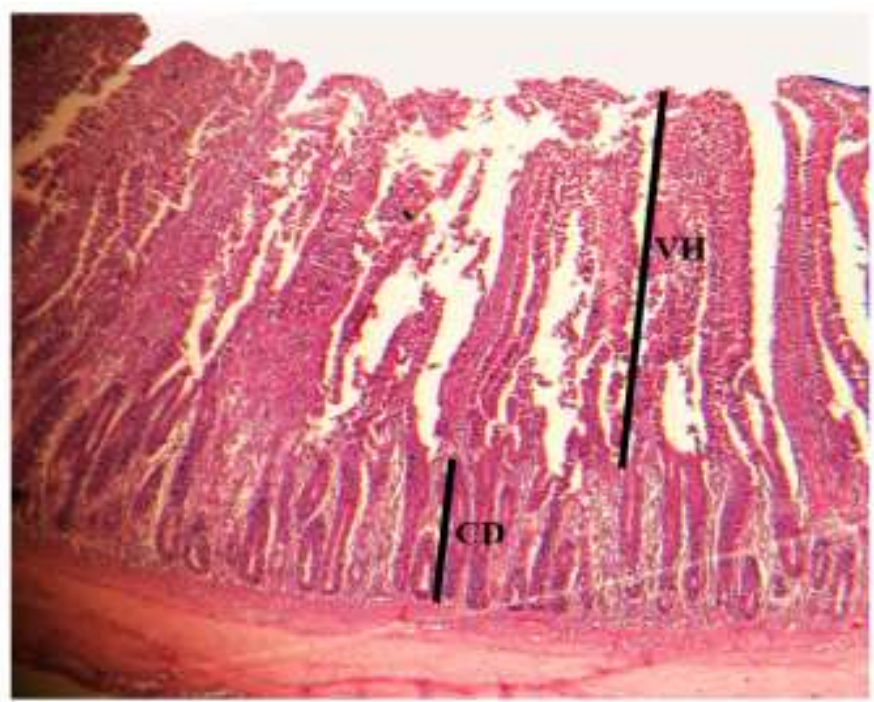

Figure 1. Example of jejunal villus height $(\mathrm{VH})$ and crypt depth (CD) determination in $20 \%$ CP supplemented with betaine.

\section{Determination of nutrient retention}

After 35 days of dietary treatments, 40 chickens (two per replicate) were randomly selected for a digestion trial to measure nutrient retention for each experimental diet. The chickens were housed in individual cages and fed the tested diet for a five-day collection period according the procedure used by El-Husseiny et al. (2007). The chickens were given an experimental diet containing $0.4 \% \mathrm{Fe}_{2} \mathrm{O}_{3}$ as an indicator to determine the start and the end of excreta collection (Marais, 2000). At the end of collection period, the chickens were fed diets without the indicator. Excreta collection was started when the red color appeared in the excreta and was terminated when the red color of the excreta disappeared (Ratriyanto et al., 2014). During the excreta collection, $2 \mathrm{ml} 0.2 \mathrm{~N} \mathrm{H}_{2} \mathrm{SO}_{4}$ was spread periodically on the excreta to minimize further bacterial fermentation. The excreta were pooled and dried under the sun thereafter. Samples of the diets and excreta were milled through a $1.0 \mathrm{~mm}$ mesh screen prior to analysis. The determination of the dry matter (DM) and CP was performed as outlined by Association of Official Analytical Chemists (AOAC, 2001).

\section{Statistical analysis}

The data were submitted to a two-way analysis of variance with the following model: $y_{i j k}=\mu+\alpha_{i}+\beta_{j}+\alpha \beta_{i j}+\varepsilon_{i j k}$, where $\mu=$ the general mean, $\alpha_{i}=$ the effect of protein levels, $\beta_{j}=$ the effect of betaine supplementation, $\alpha \beta_{i j}=$ the interaction effect of protein levels and betaine supplementation, and $\varepsilon_{\mathrm{ijk}}=$ an experimental error. If the variance analysis results indicated a significant effect, it was then subjected to Duncan's Multiple Range Test at $\mathrm{P}<0.05$ (Steel et al., 1996). All statistical analyses were performed using the R program, version 3.5.3 (R Core Team, 2019).

\section{Results and Discussion}

\section{Small intestine characteristics}

No interaction occurred between the protein level and betaine supplementation on small intestine characteristics (Table 2), which indicates that these values remained the same for all protein levels, with or without betaine supplementation. The birds fed $20 \%$ CP exhibited a longer ileum $(78.77 \mathrm{~cm}$ vs $73.88 \mathrm{~cm}, \mathrm{P}<0.01)$, which corresponded to a longer small intestine (199.61 cm vs $192.31 \mathrm{~cm}, \mathrm{P}=0.04)$. Furthermore, betaine supplementation significantly increased the ileum ( $78.27 \mathrm{~cm}$ vs $74.38 \mathrm{~cm}, \mathrm{P}=0.02$ ) and small intestine length $(199.95 \mathrm{~cm}$ vs $191.97 \mathrm{~cm}$, $\mathrm{P}=0.03)$ as well as the villus height $(376 \mu \mathrm{m}$ vs $318 \mu \mathrm{m}, \mathrm{P}<0.01)$ and villus height/crypt depth ratio (4.83 vs $4.01, P=0.03$ ) compared to that of a nonsupplemented diet, indicating more gut surface area for nutrient absorption. This finding is confirmed by the higher nutrient retention in this group (Tables 3 and 4 ). These results are comparable with observation in broilers where the jejunal villus height ranged between 318-397 $\mu \mathrm{m}$, crypt depth ranged between $60-68 \mu \mathrm{m}$, and villus height/crypt depth ratio ranged between 3.27-8.25 (Liu et al., 2019).

This research confirms that intestinal morphology was improved by betaine supplementation. Betaine supplementation stabilizes the mucosal structure in birds due to its osmolytic property, which is indicated by a longer small intestine, a higher villus, and a higher villus/crypt ratio (Table 2 ). This finding agrees with previous observation, in which betaine increased the villus/crypt ratio and small intestine length in broilers aged 21 days, indicating that betaine altered the intestinal cells' morphology and stabilized the gut mucosa structure (Kettunen et al., 2001b; Kettunen et al., 2001c). Other observations of broiler chickens also revealed that 
Table 2. Small intestine characteristics in broilers submitted to different protein regimes supplemented with betaine

\begin{tabular}{|c|c|c|c|c|c|c|c|c|}
\hline \multicolumn{2}{|c|}{ Treatments } & $\begin{array}{l}\text { Duodenum } \\
\text { length } \\
(\mathrm{cm})\end{array}$ & $\begin{array}{l}\text { Jejunum } \\
\text { length }(\mathrm{cm})\end{array}$ & lleum length $(\mathrm{cm})$ & $\begin{array}{c}\text { Small } \\
\text { Intestine } \\
\text { length }(\mathrm{cm})\end{array}$ & $\begin{array}{c}\text { Villus } \\
\text { Height }(\mu \mathrm{m})\end{array}$ & $\begin{array}{l}\text { Crypt Depth } \\
(\mu \mathrm{m})\end{array}$ & $\begin{array}{c}\text { Villus/Crypt } \\
\text { Ratio }\end{array}$ \\
\hline \multicolumn{9}{|c|}{ Interaction protein $\times$ betaine } \\
\hline 20 & Control & $36.25 \pm 2.10$ & $83.31 \pm 4.91$ & $77.38 \pm 4.89$ & $196.94 \pm 9.96$ & $309 \pm 41$ & $79 \pm 9.7$ & $3.91 \pm 0.05$ \\
\hline 20 & Betaine & $37.00 \pm 2.83$ & $85.13 \pm 1.18$ & $80.16 \pm 2.09$ & $202.28 \pm 5.22$ & $352 \pm 36$ & $71 \pm 3.3$ & $4.96 \pm 0.70$ \\
\hline 23 & Control & $33.75 \pm 0.87$ & $81.88 \pm 5.48$ & $71.38 \pm 1.75$ & $187.00 \pm 6.12$ & $327 \pm 16$ & $80 \pm 9.0$ & $4.10 \pm 0.33$ \\
\hline 23 & Betaine & $37.50 \pm 3.49$ & $83.75 \pm 4.91$ & $76.38 \pm 1.80$ & $197.63 \pm 0.75$ & $400 \pm 25$ & $85 \pm 4.4$ & $4.69 \pm 0.51$ \\
\hline \multicolumn{2}{|c|}{$P$ value } & 0.26 & 0.98 & 0.46 & 0.43 & 0.40 & 0.28 & 0.77 \\
\hline \multicolumn{9}{|c|}{ Effect of protein } \\
\hline \multicolumn{2}{|l|}{20} & $36.63 \pm 2.34$ & $84.22 \pm 3.45$ & $78.77 \pm 3.78^{\mathrm{a}}$ & $199.61 \pm 7.90^{\mathrm{a}}$ & $330 \pm 42$ & $75 \pm 7.7$ & $4.43 \pm 0.73$ \\
\hline \multicolumn{2}{|l|}{23} & $35.63 \pm 3.09$ & $82.81 \pm 4.92$ & $73.88 \pm 3.14^{b}$ & $192.31 \pm 6.97^{b}$ & $363 \pm 44$ & $83 \pm 7.0$ & $4.40 \pm 0.50$ \\
\hline \multicolumn{2}{|c|}{$P$ value } & 0.44 & 0.54 & $<0.01$ & 0.04 & 0.07 & 0.20 & 0.40 \\
\hline \multicolumn{9}{|c|}{ Effect of betaine } \\
\hline \multicolumn{2}{|c|}{ Control } & $35.00 \pm 2.00$ & $82.59 \pm 4.88$ & $74.38 \pm 4.67^{b}$ & $191.97 \pm 9.32^{b}$ & $318 \pm 30^{b}$ & $80 \pm 8.4$ & $4.01 \pm 0.24^{a}$ \\
\hline \multicolumn{2}{|c|}{ Betaine } & $37.25 \pm 2.95$ & $84.44 \pm 3.39$ & $78.27 \pm 2.71^{a}$ & $199.95 \pm 4.26^{a}$ & $376 \pm 38^{a}$ & $78 \pm 8.5$ & $4.83 \pm 0.57^{b}$ \\
\hline \multicolumn{2}{|c|}{$P$ value } & 0.10 & 0.43 & 0.02 & 0.03 & $<0.01$ & 0.81 & 0.03 \\
\hline
\end{tabular}

supplemental betaine enhanced the villus height and villus height/crypt depth ratio in the duodenum and jejunum (Liu et al., 2019). In another study, betaine increased the villus height associated with the absorptive area in broilers, although the small intestine length was not affected (Dos Santos et al., 2018). Increasing the villus height supports better nutrient digestion and absorption, leading to an improvement in growth performance in the long term (Dos Santos et al., 2018). In contrast to this result, Sakomura et al. (2013) did not observe any alteration in villus height or crypt depth in broilers receiving betaine supplementation.

Several of betaine's modes of action may explain the positive response in intestinal characteristics to supplemental betaine. As a methyl donor, betaine improves protein and energy metabolism, leading to an improvement in the intestinal cells' proliferation as indicated by the longer small intestine and higher villus in this study (Ratriyanto and Mosenthin, 2018; Liu et al., 2019). Furthermore, the osmolytic function of betaine helps the intestine cope with the high osmotic pressure created by unabsorbed nutrients in the lumen intestine, thus supporting the intestine's development (Ratriyanto and Mosenthin, 2018; Dos Santos et al., 2018; Ratriyanto and Prastowo, 2019). Betaine also lessens oxidative damage to the intestine due to its antioxidant activity (Liu et al., 2019).

\section{Dry matter and crude protein retention}

No interaction occurred between CP levels and betaine supplementation on DM and CP retention (Tables 3 and 4 ), which indicates that nutrient retention remained the same for the two $\mathrm{CP}$ levels, with or without betaine supplementation. The CP levels did not affect DM intake, excretion, or grams of retention. However, birds fed $20 \%$ CP levels generated a higher percentage of $\mathrm{DM}$ retention relative to $\mathrm{DM}$ intake (77.92\% vs $75.88 \%, P=0.04)$, indicating a more efficient nutrient digestion and absorption (De Faria Filho et al., 2007). Improvement in the percentage of DM retention is associated with an improvement in the small intestine length in this study (Table 2), indicating a higher surface area for nutrient absorption.

Furthermore, compared with that of a nonsupplemented diet, betaine supplementation reduced DM excretion (24.68 g vs $27.87 \mathrm{~g}$, $\mathrm{P}=0.01$ ) without affecting $\mathrm{DM}$ intake, leading to an increase in DM retention both in grams $(89.89 \mathrm{~g}$ vs $85.23 \mathrm{~g}, \mathrm{P}=0.04)$ and by percentage $(78.45 \%$ vs $75.35 \%, P<0.01)$. These findings indicated that betaine yielded a better use of nutrients than a non-supplemented diet. Improvement in DM retention due to betaine supplementation could be attributed to the osmolytic property of betaine, which improved the intestinal cells' structure and the growth of intestinal microbiota, leading to enhanced nutrient digestion and absorption (Kettunen et al., 2001a; Ratriyanto and Prastowo, 2019). Dietary betaine also alleviated the digesta osmolality in the intestine, enabling higher nutrient absorption (Hamidi et al., 2010). Similar to this result, betaine addition enhanced the percentage of organic matter (OM) or DM retention in broiler chickens (El-Husseiny et al., 2007) and quails (Ratriyanto and Prastowo, 2019). Yet another observation of broiler chickens did not show any influence by betaine in the percentage of DM retention (Attia et al., 2005).

In contrast with DM intake, feeding a diet of $20 \%$ CP yielded a lower CP intake compared with feeding $23 \% \mathrm{CP}$ (22.76 g vs $26.19 \mathrm{~g}, \mathrm{P}<0.01)$. Feeding $20 \% \mathrm{CP}$ also reduced the grams of CP excretion compared with feeding $23 \%$ CP $(4.19 \mathrm{~g}$ vs $5.78 \mathrm{~g}, \mathrm{P}<0.01)$. However, birds fed $20 \% \mathrm{CP}$ generated a higher percentage of $\mathrm{CP}$ retention relative to $\mathrm{CP}$ intake $(81.55 \%$ vs $77.93 \%, \mathrm{P}<0.01)$. These results indicated that feeding a diet of $20 \%$ $\mathrm{CP}$ yielded a more efficient use of dietary $\mathrm{CP}$. Feeding a high CP content leads to inefficiency due to high undigested and unabsorbed $\mathrm{CP}$ in the intestine, which is then excreted from the body (Moosavi et al., 2012). Moreover, feeding a high level of CP stimulates amino acid oxidation excesses and leads to low protein utilization (Blair et al., 1999). In accordance with this observation, 
Table 3. Dry matter retention per bird per day in broilers submitted to different protein regimes supplemented with betaine

\begin{tabular}{|c|c|c|c|c|c|}
\hline Tre & ments & Intake $(\mathrm{g})$ & Excretion $(\mathrm{g})$ & Retention (g) & Retention (\%) \\
\hline \multicolumn{6}{|c|}{ Interaction protein $\times$ betaine } \\
\hline 20 & Control & $113.02 \pm 8.26$ & $27.09 \pm 3.26$ & $85.93 \pm 7.35$ & $76.01 \pm 2.63$ \\
\hline 20 & Betaine & $114.63 \pm 6.03$ & $23.11 \pm 1.55$ & $91.53 \pm 5.49$ & $79.82 \pm 1.33$ \\
\hline 23 & Control & $113.18 \pm 2.98$ & $28.66 \pm 2.74$ & $84.53 \pm 2.60$ & $74.70 \pm 2.12$ \\
\hline 23 & Betaine & $114.54 \pm 1.84$ & $26.28 \pm 2.47$ & $88.26 \pm 1.60$ & $77.07 \pm 1.89$ \\
\hline$P$ value & & 0.96 & 0.49 & 0.67 & 0.44 \\
\hline \multicolumn{6}{|c|}{ Effect of protein } \\
\hline 20 & & $113.82 \pm 6.87$ & $25.10 \pm 3.19$ & $88.73 \pm 6.79$ & $77.92 \pm 2.81^{a}$ \\
\hline 23 & & $113.86 \pm 2.44$ & $27.47 \pm 2.76$ & $86.39 \pm 2.83$ & $75.88 \pm 2.27^{b}$ \\
\hline$P$ value & & 0.98 & 0.06 & 0.30 & 0.04 \\
\hline \multicolumn{6}{|c|}{ Effect of betaine } \\
\hline Control & & $113.10 \pm 5.85$ & $27.87 \pm 2.96^{\mathrm{a}}$ & $85.23 \pm 5.25^{b}$ & $75.35 \pm 2.36^{b}$ \\
\hline Betaine & & $114.59 \pm 4.20$ & $24.69 \pm 2.57^{\mathrm{b}}$ & $89.89 \pm 4.19^{a}$ & $78.45 \pm 2.12^{\mathrm{a}}$ \\
\hline$P$ value & & 0.55 & 0.01 & 0.04 & $<0.01$ \\
\hline
\end{tabular}

Table 4. Crude protein retention per bird per day in broilers submitted to different protein regimes supplemented with betaine

\begin{tabular}{|c|c|c|c|c|c|}
\hline \multicolumn{2}{|c|}{ Treatments } & Intake (g) & Excretion $(\mathrm{g})$ & Retention (g) & Retention (\%) \\
\hline \multicolumn{6}{|c|}{ Interaction protein $\times$ betaine } \\
\hline 20 & Control & $22.60 \pm 1.65$ & $4.42 \pm 0.31$ & $18.18 \pm 1.74$ & $80.35 \pm 2.26$ \\
\hline 20 & Betaine & $22.93 \pm 1.21$ & $3.96 \pm 0.76$ & $18.96 \pm 1.00$ & $82.74 \pm 2.93$ \\
\hline 23 & Control & $26.03 \pm 0.69$ & $6.06 \pm 0.41$ & $19.97 \pm 0.46$ & $76.72 \pm 1.17$ \\
\hline 23 & Betaine & $26.34 \pm 0.42$ & $5.50 \pm 0.48$ & $20.85 \pm 0.48$ & $79.14 \pm 1.72$ \\
\hline \multicolumn{2}{|l|}{$P$ value } & 0.98 & 0.81 & 0.91 & 0.98 \\
\hline \multicolumn{6}{|c|}{ Effect of protein } \\
\hline \multicolumn{2}{|l|}{20} & $22.76 \pm 1.37^{\mathrm{b}}$ & $4.19 \pm 0.60^{\mathrm{b}}$ & $18.57 \pm 1.40^{\mathrm{b}}$ & $81.55 \pm 2.77^{a}$ \\
\hline \multicolumn{2}{|l|}{23} & $26.19 \pm 0.56^{a}$ & $5.78 \pm 0.52^{\mathrm{a}}$ & $20.41 \pm 0.64^{\mathrm{a}}$ & $77.93 \pm 1.89^{b}$ \\
\hline \multicolumn{2}{|l|}{$P$ value } & $<0.01$ & $<0.01$ & $<0.01$ & $<0.01$ \\
\hline \multicolumn{6}{|c|}{ Effect of betaine } \\
\hline \multicolumn{2}{|l|}{ Control } & $24.32 \pm 2.16$ & $5.24 \pm 0.93^{a}$ & $19.08 \pm 1.53$ & $78.53 \pm 2.56^{b}$ \\
\hline \multicolumn{2}{|l|}{ Betaine } & $24.64 \pm 1.99$ & $4.73 \pm 1.01^{\mathrm{b}}$ & $19.90 \pm 1.24$ & $80.94 \pm 2.95^{a}$ \\
\hline \multicolumn{2}{|l|}{$P$ value } & 0.53 & 0.04 & 0.09 & 0.02 \\
\hline
\end{tabular}

previous studies showed that reducing dietary $\mathrm{CP}$ also reduced nitrogen excretion (Blair et al., 1999; De Faria Filho et al., 2007).

Betaine supplementation reduced $\mathrm{CP}$ excretion (4.73 g vs $5.24 \mathrm{~g}, P=0.04$ ) without affecting CP intake compared to that of a nonsupplemented diet and led to an increase in the percentage of CP retention $(80.94 \%$ vs $78.53 \%$, $\mathrm{P}=0.02$ ) as presented in Table 4. Liu et al. (2019) observed an improvement in trypsin activity in the small intestine, which could be attributed to the enhanced CP retention. As an organic osmolyte, betaine adheres to the surface of biopolymers and helps proteins fold more compactly, leads to an improvement in protein digestion (Liu et al., 2019). The osmoprotective function of betaine also helps to maintain the intestinal cells' integrity, leading to enhanced nutrient absorption (Sakomura et al., 2013). Improvements in CP retention due to betaine supplementation have been observed previously in broiler chickens (El-Husseiny et al., 2007), laying hens (Attia et al., 2016), and ducks (Ahmed et al., 2018).

\section{Conclusions}

The findings of this experiment showed that diets with $20.0 \% \mathrm{CP}$ generated better small intestine characteristics than diets with $23.0 \% \mathrm{CP}$ as indicated by the longer ileum and total length of the small intestine. This improvement was associated with less CP excretion and improved 
DM and CP retention. Furthermore, dietary betaine supplementation enhanced the ileum, total length of the small intestine, and villus-to-crypt ratio, indicating a greater surface area for nutrient absorption. This enhancement was reflected in the reduction of $\mathrm{DM}$ and $\mathrm{CP}$ excretion and the improvement in $\mathrm{DM}$ and $\mathrm{CP}$ retention.

\section{References}

Ahmed, M. M. N., Z. S. H. Ismail, and A. A. A. Abdel-Wareth. 2018. Effect of dietary supplementation of prebiotic, betaine and their combination on growth performance, nutrient digestibility, carcass criteria and cecum microbial population of ducks under hot environmental conditions. Egypt. Poult. Sci. J. 38: 289-304.

AOAC. 2001. Official Methods of Analysis of the Association of Official Analytical Chemists. Association of Official Analytical Chemists, Washington DC.

Attia, Y. A., A. E. E. Abd-El-Hamid, A. A. Abedalla, M. A. Berika, M. A. Al-Harthi, O. Kucuk, K. Sahin, and B. M. Abou-Shehema. 2016. Laying performance, digestibility and plasma hormones in laying hens exposed to chronic heat stress as affected by betaine, vitamin $\mathrm{C}$, and/or vitamin $\mathrm{E}$ supplementation. Springerplus. 5: 16-19.

Attia, Y. A., R. A. Hassan, M. H. Shehatta, and S. B. Abd El-Hady. 2005. Growth, carcass quality and serum constituents of slow growing chicks as affected by betaine addition to diets containing 2. Different levels of methionine. Int. J. Poult. Sci. 4: 856-865.

Blair, R., J. P. Jacob, S. Ibrahim, and P. Wang. 1999. A quantitative assessment of reduced protein diets and supplements to improve nitrogen utilization. J. Appl. Poult. Res. 8: 25-47.

Chand, N., S. Naz, H. Maris, R. U. Khan, S. Khan, and M. S. Qureshi. 2017. Effect of betaine supplementation on the performance and immune response of heat stressed broilers. Pak. J. Zool. 49: 1857-1862.

Daghir, N. 2009. Nutritional strategies to reduce heat stress in broilers and broiler breeders. Lohmann Inf. 44: 6-15.

De Faria Filho, D. E., D. M. B. Campos, K. A. Alfonso-Torres, B. S. Vieira, P. S. Rosa, A. M. Vaz, M. Macari, and R. L. Furlan. 2007. Protein levels for heat-exposed broilers: Performance, nutrients digestibility, and energy and protein metabolism. Int. J. Poult. Sci. 6: 187-194.

Dos Santos, T. T., S. C. Dassi, C. R. C. Franco, C. R. V. da Costa, S. A. Lee, and A. V. Fisher da Silva. 2018. Influence of fibre and betaine on development of the gastrointestinal tract of broilers between hatch and $14 \mathrm{~d}$ of age. Anim. Nutr. 5: 163173.
El-Husseiny, O. M., M. A. Abo-El-Ella, M. O. AbdElsamee, and M. M. Abd-Elfattah. 2007. Response of broilers performance to dietary betaine and folic acid at different methionine levels. Int. J. Poult. Sci. 6: 515523.

Esmailzadeh, L., M. Shivazad, A. A. Sadeghi, and M. Karimitorshizi. 2016. Performance, intestinal morphology and microbiology of broiler chickens fed egg powder in the starter diet. Rev. Bras. Cienc. Avic. 18: 705-710.

Gous, R. M., A. S. Faulkner, and H. K. Swatson. 2018. The effect of dietary energy:protein ratio, protein quality and food allocation on the efficiency of utilisation of protein by broiler chickens. Br. Poult. Sci. 59: 100109.

Hamidi, H., R. Jahanian, and J. Pourreza. 2010. Effect of dietary betaine on performance, immunocompetence and gut contents osmolarity of broilers challenged with a mixed coccidial infection. Asian J. Anim. Vet. Adv. 5: 193-201.

Kettunen, H., S. Peuranen, and K. Tiihonen 2001a. Betaine aids in the osmoregulation of duodenal epithelium of broiler chicks, and affects the movement of water across the small intestinal epithelium in vitro. Comp. Biochem. Physiol. - A Mol. Integr. Physiol. 129: 595-603.

Kettunen, H., S. Peuranen, K. Tiihonen, and M. Saarinen. 2001b. Intestinal uptake of betaine in vitro and the distribution of methyl groups from betaine, choline, and methionine in the body of broiler chicks. Comp. Biochem. Physiol. - A Mol. Integr. Physiol. 128: 269-278.

Kettunen, H., K. Tiihonen, S. Peuranen, M. T. Saarinen, and J. C. Remus. 2001c. Dietary betaine accumulates in the liver and intestinal tissue and stabilizes the intestinal epithelial structure in healthy and coccidiainfected broiler chicks. Comp. Biochem. Physiol. - A Mol. Integr. Physiol. 130: 759 769.

Li, Y. X., Y. Q. Qang, Y. Z. Pang, J. X. Li, X. H. Xie, T. J. Guo, and W. Q. Li. 2011. The effect of crude protein level in diets on laying performance, nutrient digestibility of yelow quails. Int. J. Poult. Sci. 10: 110-112.

Liu, W., Y. Yuan, C. Sun, B. Balasubramanian, Z. Zhao, and L. An. 2019. Effects of dietary betaine on growth performance, digestive function, carcass traits, and meat quality in indigenous yellow-feathered broilers under long-term heat stress. Animals. 9: 506.

Marais, J. P. 2000. Use of Markers. In: Farm Animal Metabolism and Nutrition. J. P. F. D'Mello, editor. Farm Animal Metabolism and Nutrition. CABI Publishing, Wallingford. p. 255-277.

Metzler-Zebeli, B. U., M. Eklund, and R. Mosenthin. 2009. Impact of osmoregulatory and methyl donor functions 
of betaine on intestinal health and performance in poultry. Worlds. Poult. Sci. J. 65: 419-442.

Moosavi, M., M. Chaji, S. Rahimnahal, and A. R. Kazemi. 2012. Effect of different levels of energy and protein with constant ratio on performance and carcass characteristics in broiler chickens. Int. Res. J. Appl. Basic Sci. 3: 2485-2488.

National Research Council. 1994. Nutrient Requirements of Poultry. $9^{\text {th }}$ edn. National Academic Press, Washington DC.

$\mathrm{R}$ Core Team. 2019. R: A Language and Environment for Statistical Computing. $\mathrm{R}$ Foundation for Statistical Computing, Vienna.

Rao, S. V. R., M. V. L. N. Raju, A. K. Panda, P. Saharia, and G. S. Sunder. 2011. Effect of supplementing betaine on performance, carcass traits and immune responses in broiler chicken fed diets containing different concentrations of methionine. Asian-Australasian J. Anim. Sci. 24: 662669.

Rashid, H. O. S., E. E. M. Huwaida, and A. Y. Ibrahim. 2012. Effect of dietary protein level and strain on growth performance of heat stressed broiler chicks. Int. J. Poult. Sci. 11: 649-653.

Ratriyanto, A., R. Indreswari, and Sunarto. 2014. Effects of protein levels and supplementation of methyl group donor on nutrient digestibility and performance of broiler chickens in the tropics. Int. J. Poult. Sci. 13: 575-581.

Ratriyanto, A. and R. Mosenthin. 2018. Osmoregulatory function of betaine in alleviating heat stress in poultry. J. Anim.
Physiol. Anim. Nutr. (Berl). 102: 16341650.

Ratriyanto, A., R. Mosenthin, E. Bauer, and M. Eklund. 2009. Metabolic, osmoregulatory and nutritional functions of betaine in monogastric animals. Asian-Australasian J. Anim. Sci. 22: 1461-1476.

Ratriyanto, A., and S. Prastowo. 2019. Floor space and betaine supplementation alter the nutrient digestibility and performance of Japanese quail in a tropical environment. J. Therm. Biol. 18: 80-86.

Sakomura, N. K., N. A. A. Barbosa, F. A. Longo, E. P. da Silva, M. A. Bonato, and J. B. Fernandes. 2013. Effect of dietary betaine supplementation on the performance, carcass yield, and intestinal morphometrics of broilers submitted to heat stress. Rev. Bras. Ciência Avícola. 15: 105-112.

Sayed, M. A. M. and J. Downing. 2011. The effects of water replacement by oral rehydration fluids with or without betaine supplementation on performance, acidbase balance, and water retention of heatstressed broiler chickens. Poult. Sci. 90: 157-167.

Steel, R. G. D., J. H. Torrie, and D. A. Dickey. 1996. Principles and Procedures of Statistics: A Biometrical Approach. McGraw-Hill, New York.

Weiss, E., M. Eklund, A. Semaskaite, R. Urbaityte, B. Metzler-Zebeli, N. Sauer, A. Ratriyanto, R. Gruzauskas, and R. Mosenthin. 2013. Combinations of feed additives affect ileal fibre digestibility and bacterial numbers in ileal digesta of piglets. Czech J. Anim. Sci. 58: 351-359. 